Tenda, P. E., \& Toyo, E. M. (2021). Anti-Cholesterolaemic Activity of Mulberry (Morus australis Poir) Ethanol Extract in Increasing HDL Levels and Inhibiting Formation of Foam Cells on Rat. JURNAL INFO KESEHATAN, 19(1), 77-84. https://doi.org/10.31965/infokes.Vol19/ss1.497

Jurnal Info Kesehatan

Vol. 19, No. 1, June 2021, pp. 77-84

P-ISSN 0216-504X, E-ISSN 2620-536X

DOI:10.31965/infokes.Vol19Iss1.497

Journal homepage:http://jurnal.poltekeskupang.ac.id/index.php/infokes

\title{
Anti-Cholesterolemic Activity of Mulberry (Morus australis Poir) Ethanol Extract in Increasing HDL Levels and Inhibiting Formation of Foam Cells on Rat
}

\section{Priska Ernestina Tenda ${ }^{1 a^{*}}$, Eleonora Maryeta Toyo ${ }^{2 b}$}

${ }^{1 .}$ Department of Pharmacy, Poltekkes Kemenkes Kupang, Kupang, East Nusa Tenggara, Indonesia.

${ }^{2}$ Nusaputera College of Pharmacy, Semarang, Central Java, Indonesia.

${ }^{\text {a }}$ Email address: priskafarmasikupang@gmail.com

${ }^{\mathrm{b}}$ Email address: eleonorareth@gmail.com

\begin{abstract}
Mulberry leaves are one of the medicinal plants empirically used by people to reduce cholesterol levels. Previous study found that mulberry leaves contain flavonoids, act as cholesterol-lowering and tannins function to inhibit the absorption of food, including fat in the GI tract. The objective of this study is to determine the effect of mulberry leaf ethanol extract on increased HDL levels and to determine the inhibition of the formation of foam cells in male Wistar strain rats given the atherogenic diet. Thirty male Wistar rats were divided into six groups, which were normal group, negative control, positive control, and three groups of mulberry leaf extract at a dose of 25,50 , and $100 \mathrm{mg} / 200 \mathrm{~g}$ BW rats, respectively. The HDL levels were measured pre- and post- treatment on days $0,28,35$ and 42 . The results showed that the most effective dose augmenting the HDL as well as inhibited the formation of aortic wall foam cell was the ethanol extract at a dose of $100 \mathrm{mg} / 200 \mathrm{~g} \mathrm{BW}$. In conclusion, mulberry leaves ethanolic extract have the potency to be developed as a natural cholesterol-lowering agent.
\end{abstract}

Keywords: Ethanol Extract of Mulberry Leaves, HDL Level, Foam Cells.

*Corresponding Author:

Priska Ernestina Tenda

Department of Pharmacy, Poltekkes Kemenkes Kupang, Kupang, East Nusa Tenggara, Indonesia. Email: priskafarmasikupang@gmail.com

(C) The Author(s) 2021. This article is distributed under the terms of the Creative Commons Attribution 4.0 International License (http://creativecommons.org/licenses/by/4.0/), which permits unrestricted use, distribution, and reproduction in any medium, provided you give appropriate credit to the original author(s) and the source, provide a link to the Creative Commons license, and indicate if changes were made. The Creative Commons Public Domain Dedication waiver (http://creativecommons.org/publicdomain/zero/1.0/) applies to the data made available in this article, unless otherwise stated. 


\section{INTRODUCTION}

The death incidence due to coronary heart disease (CHD) in Indonesia was almost 2.0 million people aged between 15-55 years old in 2017 (Uli, et al., 2020). Based on the Indonesia national health survey in the past ten years, the number of CHD tends to increase each year and counted as the $3^{\text {rd }}$ leading mortality (Hussain, et al., 2016). Cholesterol is one of the precursors of steroid compounds which exist in the body, synthesized from acetyl-CoA and forms mevalonic acid through complex pathways (Murray, et al., 2008). Sutejo, (2006), suggested that the liver synthesizes most cholesterol and a small portion which absorbed from the diet. The presence of cholesterol in blood vessels in high amounts create deposits or plates which narrow or clog arteries that cause atherosclerosis, whichin turn has an impact on $\mathrm{CHD}(\mathrm{Xu}$, et al., 2018).

HDL is anti-atherogenic because it lifts excess cholesterol in the blood vessel tissue to the liver which is released through the bile ducts (Dewi, et al., 2012). Epidemiological evidence and its clinic present a negative relationship between HDL cholesterol and CHD. Dietary interventions can raise HDL cholesterol levels and at the same time, reduce CHD. Thus, efforts needed for prevention, for instance by using hypolipidemia drugs.

Mulberry leaf or Morus australis Poir is an herbal plant well-known by the people of Indonesia as a traditional treatment for cough, fever, diabetes, anemia, and hypertension (Hariana, 2008). Its growth is wildly and easily found in Indonesia and usually taken for its fruit. The ethanol extract of the mulberry leaf contains quercetin, where its compound belongs to the flavonoid glycoside group. Flavonoid glycosides are phenol compounds which act as protein coagulators (Lenny, 2006). Ethanol is a solubilizing solution that can dissolve tannins and flavonoids because the content of these compounds is a compound which has cholesterol-lowering properties (Chairungsi, et al., 2006). Tannins are efficacious in the process of compaction of the mucous layer of the digestive tract, thus, it inhibits the absorption of food substances, including fats and cholesterol, by the digestive tract (Smeriglio, et al., 2017).

The results of previous studies by Valacchi et al. (2014), stated that the combination of mulberry leaf and fruit extracts influence high-fat diets to regulate cholesterol transport in rat liver hence. This combination was useful for preventing obesity. Therefore, researchers were interested in conducting research on the activity of mulberry leaf ethanol extract on HDL levels and investigating the inhibition of mulberry leaf extract on the formation of foam cells in the aortic wall of male Wistar rats (Rattus novergicus) induced by atherogenic diet.

Previous study found that combination of $500 \mathrm{mg} / \mathrm{kg}$ BW extract of mulberry leaves and berries has been effectively proven regulating cholesterol transport (Valacchi, et al., 2014). Meanwhile, this study used a half reference dose $(250 \mathrm{mg} / \mathrm{kg}$ BW) since it only used the mulberry leaves. It was also known that the mulberry leaves possess similar active compound as mulberry.

\section{RESEARCH METHOD}

This study was a quasi-experimental with control design. Utilized rats as animal study, this study investigated the protective effect of mulberry leaves extract against CHD events by rising the HDL level. To pursue that objective, this study covers several steps including preparation of mulberry leaves extract, animal study, and observation of body weight, HDL level and formation of foam cells (Lamanema, 2005). 
Mulberry leaves extraction. Amount 600 grams of mulberry leaf powder was placed in a dark-colored container or bottle, added with $70 \%$ ethanol as much as $4.5 \mathrm{~L}$. The maceration took 5 days long, and filtrate was gathered at the end of the process for further concentrated using rotary evaporator. To obtain a thick extract, the solvent evaporation procedure was maintained at $50^{\circ} \mathrm{C}$.

Experimental animal. Thirty-six male Wistar rats were employed to this study with inclusion criteria which were healthy, weighing between 175-250 g, aged 16-18 weeks. The animals were maintained in controlled condition at temperature $22 \pm 3{ }^{\circ} \mathrm{C}$, humidity $44-56 \%$, and under $12 / 12$ hours of light/dark cycle, also feed normally with water ad libitum. The rats were acclimatized a week prior experiment and divided into six group randomly ( $\mathrm{n}=6$ rats each group) as follow: normal control (normal feed and water ad libitum), negative control (atherogenic diet), positive control, and three doses of ethanolic mulberry leaves extracts $(25,50$, and $100 \mathrm{mg} / 200 \mathrm{~g} \mathrm{BW}$ of rats respectively). For normal control, the rats were only administered with normal feed (Confeed PAR-S) and water ad libitum, while others were treated with atherogenic diet which contains Confed PAR-S, flour, quail egg yolk, cholic acid, lard, and water for 28 days to induce hypercholesterolemia. The negative control group was given $0.5 \% \mathrm{Na}$ $\mathrm{CMC}$, and $0.18 \mathrm{mg}$ simvastatin was administered for positive control. Meanwhile, ethanolic mulberry leaves extract groups were treated at a dose 25,50 , and $100 \mathrm{mg} / \mathrm{kg}$ BW of rats, respectively. All the treatment was delivered for 14 days starting after hypercholesterolemia was confirmed. During the study, the rats were weighed before the treatment and every week until it was terminated.

HDL measurement. The HDL level was determined by blood orbital vein puncture on the day $0,28,35$ and 42 . The measurement of day 0 was intended to know the initial level while day-28 was to confirm the hyperlipidemia state after induction. The rat's total cholesterol level that exceeds $54 \mathrm{mg} / \mathrm{dL}$ was classified as hypercholesterolemia. For investigating the effect of the treatments, the HDL level was evaluated on day 35 and 42. The HDL level $(\mathrm{mg} / \mathrm{dl})$ was determined using CHOD-PAP method as follow: $0.5 \mathrm{ml}$ venous orbital blood was centrifugated (15 min, $3000 \mathrm{rpm})$, incubated for 20 minutes $\left(20-25^{\circ} \mathrm{C}\right)$ and observed using a readable Stardust absorption photometer.

Foam cell of the aortic wall observation

Foam cell of the aortic wall observation. At the end of the study, all animals were euthanized and necropsied for isolating the abdominal aortic cross-section. It then processed of HE staining to observe the presence of the foam cells. HE staining was prepared by cutting the tissue and arranged on tissue cassette for dehydration process. Once it was blocked with paraffin liquid, cut for 3-5 $\mu \mathrm{m}$ size using microtome, and placed on the glass slide for staining using hematoxylin and eosin. The HE stains resulted on blue and red color with a clear balance that made it easier to observe on its cell component.

The data were statistically analyzed using paired-sample T-test $(p<0.05)$ to determine the effect of atherogenic diet induction between day 0 and 28. Furthermore, one-way Anova test followed by Tukey post hoc test were utilized to understand the differences of the HDL level on each group of treatment, particularly the effect of various dose of mulberry leaves extract.

\section{RESULTS AND DISCUSSION}

The ethanolic mulberry leaves extract was a thick green color, distinctive smell and had sticky also smooth appearance. The extraction process yielded $14.67 \%$ thick extract from 600 grams of mulberry leaves powder. 
In this hyperlipidemia study models, body weight was measured periodically as seen in figure 1 .

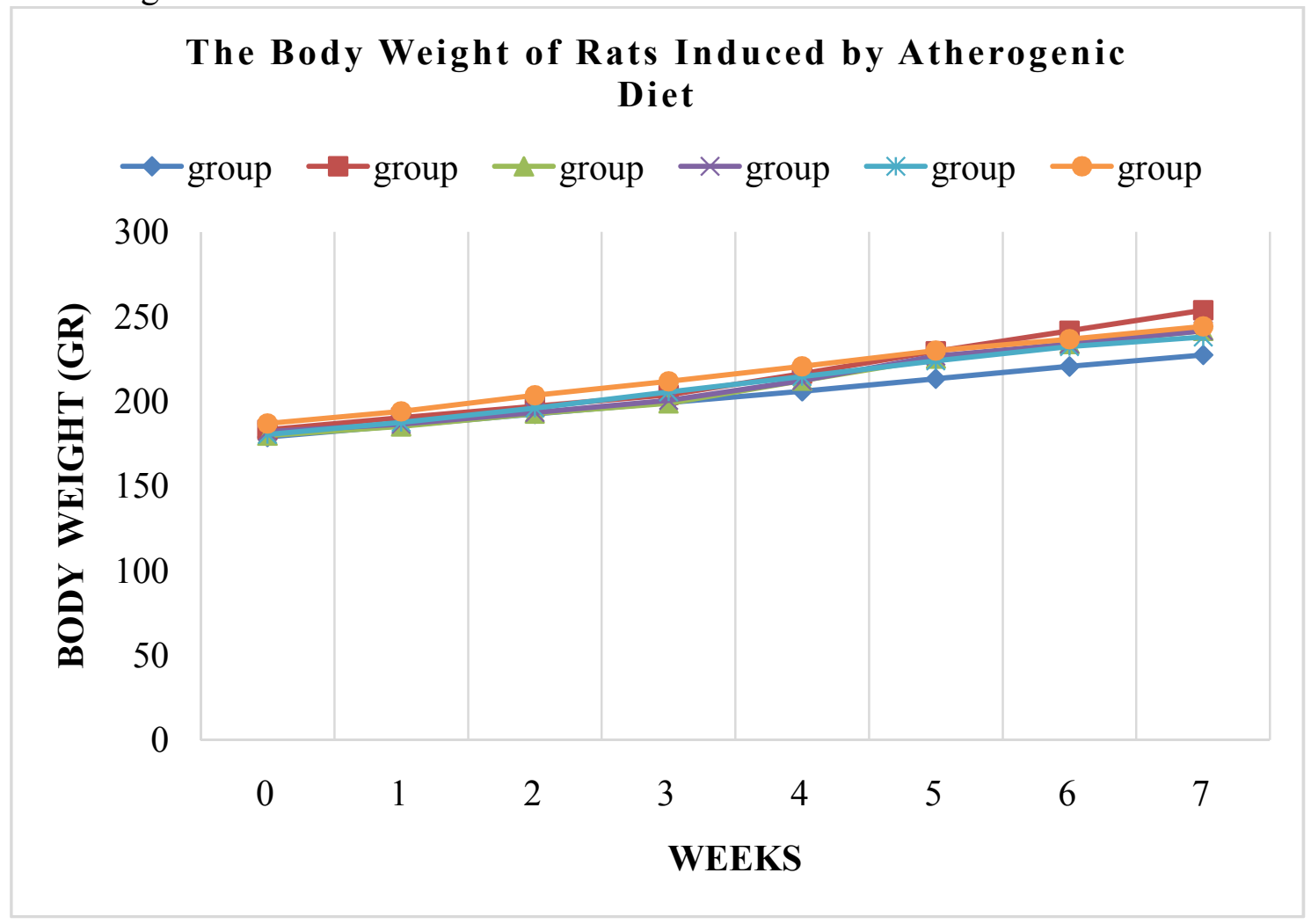

Figure 1. The body weight of animal study (Group I: normal control; II: negative control Na CMC 0.5\%; III: positive control simvastatin; IV-VI: mulberry ethanolic extract dose 25, 50, 100 $\mathrm{mg} / \mathrm{kg} \mathrm{BW}$ rats, consecutively)

The weight of the animals during almost 8 weeks of study had no significant differences $(p<0.05)$ for all groups. Although there was a slight increase of the BW, it showed the effect of atherogenic diet that could induce the weight gain. Closely observed, the negative groups showed higher trend of body weight since it induced by the diet continuously without any treatment. Overall, the body weight data revealed that there was an increase of rat's BW but still in normal range. It also proved that the diet was successful on hyperlipidemia model.

To investigate the effect of mulberry extract, the HDL level was determined. It is understood that hypercholesterolemia lowers the HDL level (Jia, et al., 2013). As described in figure 2 , the HDL level on day 0 was significant difference compared to day $28(\mathrm{p}<0.05)$ which emphasized the successful induction of atherogenic diet and supported previous statement. The HDL level then increased post treated using mulberry leaves ethanolic extract. The effect was dose dependent, higher dose administered higher level of HDL was described and it was statistically difference for each group $(\mathrm{p}<0.05)$. The extract at dose $100 \mathrm{mg} / 200 \mathrm{~g} \mathrm{BW}$ displayed the strongest effect on augmenting the HDL level that almost similar to the positive control, simvastatin. Therefore, the mulberry leaves ethanolic extract at $100 \mathrm{mg} / 200 \mathrm{~g} \mathrm{BW}$ possessed most effective anti-hyper cholesterol effect than other doses. 
Tenda, P. E., \& Toyo, E. M. (2021). Anti-Cholesterolaemic Activity of Mulberry (Morus australis Poir) Ethanol Extract in Increasing HDL Levels and Inhibiting Formation of Foam Cells on Rat. JURNAL INFO KESEHATAN, 19(1), 77-84. https://doi.org/10.31965/infokes.Vol19/ss1.497

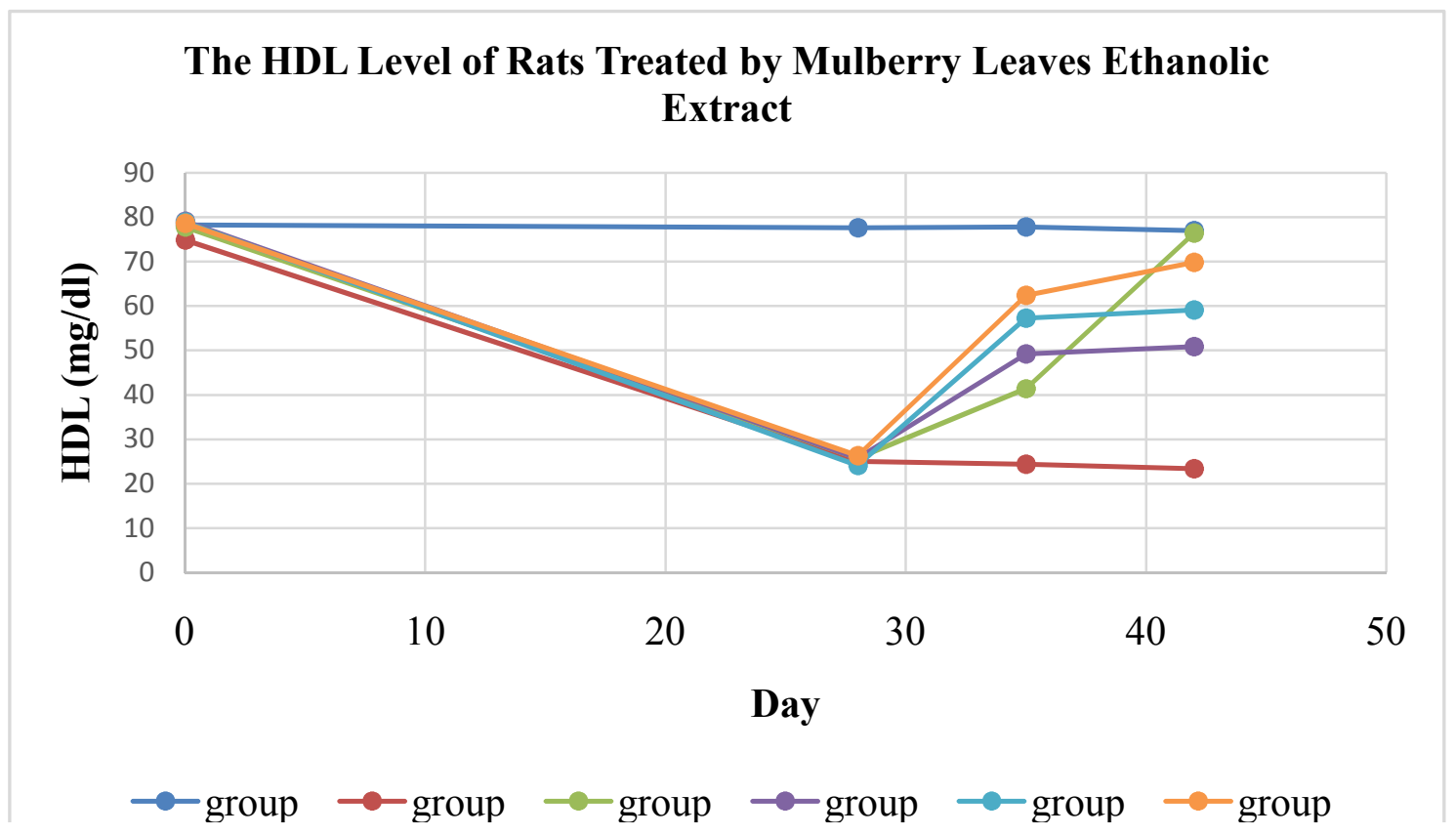

Figure 2. The HDL levels $(\mathrm{mg} / \mathrm{dL}$ ) of animal study (Group I: normal control; II: negative control Na CMC $0.5 \%$; III: positive control simvastatin; IV-VI: mulberry ethanolic extract dose $25,50,100 \mathrm{mg} / \mathrm{kg}$ BW rats, consecutively)

Mulberry leaves are believed to be an anti-hypercholesterolemia due to its flavonoids content (Syamsuhidayat\& Hutapea,1991). Flavonoids as an active component as cholesterol-lowering substances, are semi-polar that may dissolve in semi-polar solvents (Mills \& Bone, 2000). An in vitro experiment revealed that flavonoids inhibit LDL oxidation and reduce the cytotoxic effects of oxidized LDL even though the mechanism underlying this effect is not yet found.

According to Vallachi, et al., (2014), it is stated that flavonoids reduce triglyceride, LDL, and total cholesterol levels in hyperlipidemic rats. Flavonoid as a family of polyphenols attributed as an anti-cholesterol and anti-inflammatory effects in rats was induced by high-fat diets. Furthermore, polyphenols augment HDL levels and reduce LDL levels. Hence, it induces the plasma lipid level back to normal in this study. Another finding accounted flavonoids are able to increase HDL levels by increasing Apo A1 production (Ruel, et al., 2006), which role is as an enzyme cofactor for LCAT and a ligand to interact with lipoprotein receptors in tissues as well as having protective properties against atherosclerosis (Murray, et al., 2008). Furthermore, flavonoids reduce the blood cholesterol levels by inhibition of cholesterol synthesis and increase LDL receptor expression (Zeka, et al., 2017). Other compound in mulberry leaves is alkaloids which possess ability to reduce the blood cholesterol level (Zhang, et al., 2018), and tannin which is correlated with mucous production in GI tract thus inhibits the absorption of fatty food intake.

Along with HDL level that elevated after treated by mulberry extract in this study, further investigation on foam cell formation in abdominal aortic wall was intended to deeply understand the effect on cellular level. Early signs of atherosclerosis in vascular wall structure were dysfunction or vascular injury, especially endothelial, followed by lymphocyte mobilization, macrophage formation, lipid deposition, the proliferation of smooth muscle through the activity of mitogenic factors and the synthesis of the 
extracellular matrix monocytes (Wierda et al., 2010). These monocytes attach to the cytoplasmic endothelium, then infiltrate between endothelial cells and lays in the subendothelial region which then into scavenger cells and later into macrophages. Some of the function of macrophages is to ingest and cleanse fat, especially Lalith oxidized through special receptors called scavenger receptors. Then, Scavenger cells then become foam cells, which is the beginning of fatty streaks (Japardi, 2002). The gathering of macrophages in the sub intima region causes increased endothelial damage. These cells produce and secrete toxic substances and oxidative metabolites such as oxidized LDL and superoxide anions. All those processes initiate the endothelial impaired.

Figure 3 presented the histopathological profile of abdominal aortic wall to observe the presence of foam cell induced by high cholesterol level. As normal control only feed normally without induction, there was no foam cell detected. Meanwhile, in negative control, the foam cell was confirmed presenting on the smear. Similar to the negative control, the histopathological preview on the mulberry leaves extracts at dose 25 and $50 \mathrm{mg} / 100 \mathrm{~g} \mathrm{BW}$ found the appearance of foam cells though not much as negative control. On contrary, the extract at $100 \mathrm{mg} / 200 \mathrm{~kg} \mathrm{BW}$ successfully inhibited the formation of foam cell closely to the profile on positive control as well as the normal control. This result corresponds to the HDL data that higher level of HDL is equivalent to smaller production of foam cell in abdominal aortic wall as an initial sign of atherosclerosis.
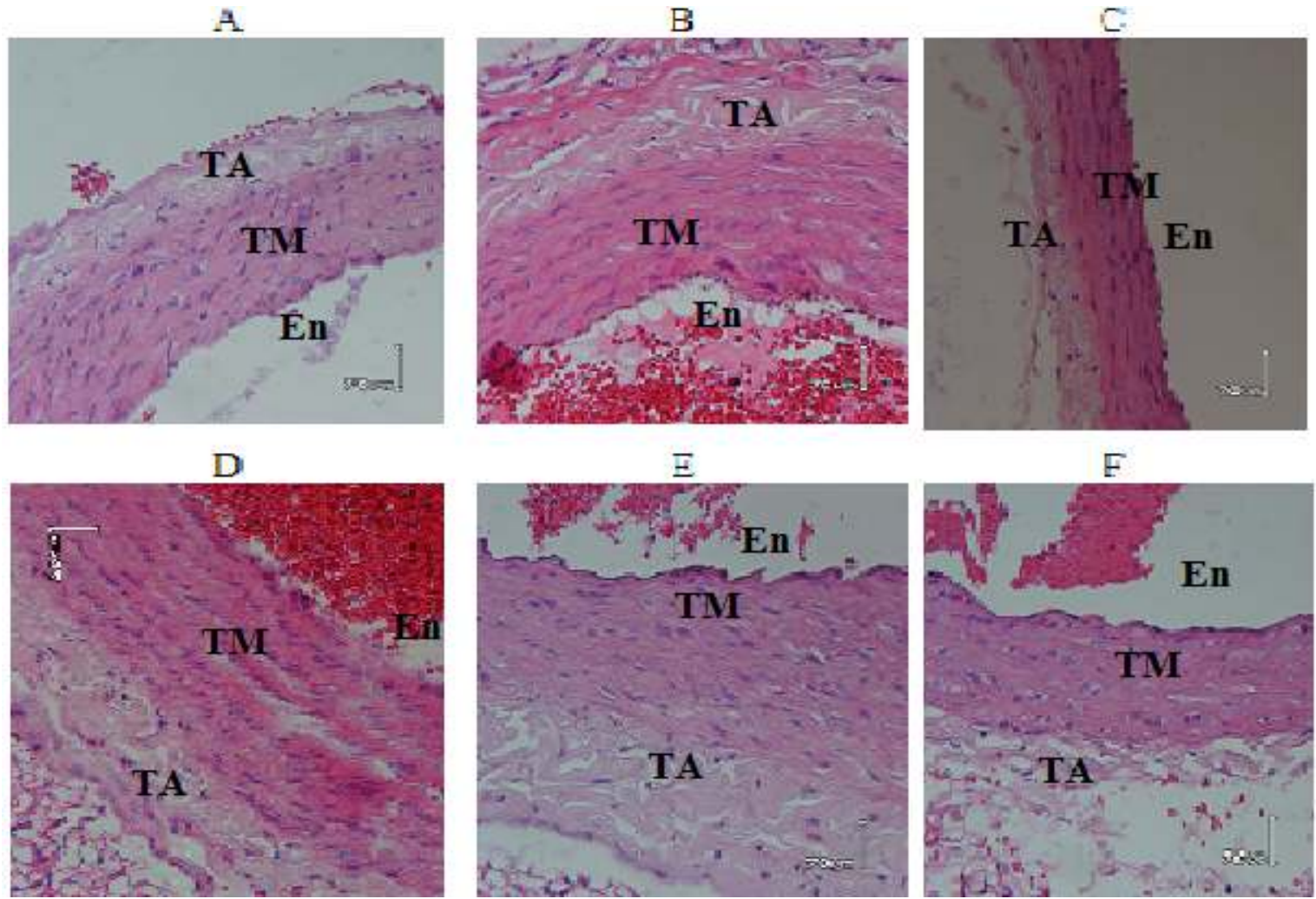

Figure 3. Histopathological profile of abdominal aortic wall (HE staining, 40x) (A: normal control; B: negative control; C: positive control; D-F: mulberry extract dose 25, 50, $100 \mathrm{mg} / 200$ g BW; En: endothelial; LA: adventisia layer; TM: tunica media; TI: tunica intima; SB: foam cells)

A study confirmed that alkaloids, one of mulberry active compound, improved endothelial function by promoting nitric oxide (Sawangjaroen, et al., 2004). Moreover, it reduced atherosclerosis lesion and inflammatory marker like ICAM-1, VCAM-1 and C-RP (Amran, et al., 2011). 
Tenda, P. E., \& Toyo, E. M. (2021). Anti-Cholesterolaemic Activity of Mulberry (Morus australis Poir) Ethanol Extract in Increasing HDL Levels and Inhibiting Formation of Foam Cells on Rat. JURNAL INFO KESEHATAN, 19(1), 77-84. https://doi.org/10.31965/infokes.Vol19/ss1.497

\section{CONCLUSION}

Based on the results, it can be concluded that the administration of mulberry leaf (Morus australis Poir.) ethanolic extract increases the HDL levels and inhibits the formation of foam cells in the aortic wall of male white Wistar strain rats induced by atherogenic diet. The most effective dose augmented the HDL as well as constrained the formation of foam cells was $100 \mathrm{mg} / 200 \mathrm{~g} \mathrm{BW}$ of rats. Further research studying on its toxicity profile is important to conduct since the anti-hypercholesterolemia treatment routinely requires long duration.

\section{REFERENCES}

Amran, A. A., Zakaria, Z., Othman, F., Das, S., Al-Mekhlafi, H. M., \& Nordin, N. A. M. (2011). Changes in the vascular cell adhesion molecule-1, intercellular adhesion molecule-1 and c-reactive protein following administration of aqueous extract of piper sarmentosum on experimental rabbits fed with cholesterol diet. Lipids in health and disease, 10(1), 1-8. doi:https://doi.org/10.1186/1476$511 \mathrm{X}-10-2$

Chairungsi, N., Jumpatong, K., Phutdhawong, W., \& Buddhasukh, D. (2006). Solvent effects in electrocoagulation of selected plant pigments and tannin. Molecules, 11(5), 309-317. doi: https://doi.org/10.3390/11050309

Dewi, Y. R., Santoso, L. M., \& Tibrani, M. M. (2012). Pineapple (Ananascomosus (L.)Merr.)Juice activity test on total cholesterol and blood triglycerides of mice (Musmusculus L.) and their contribution to learning biology in high school. Skripsi. FKIP Sriwijaya University

Hariana, A. (2008). Tanaman Obat dan Khasiatnya. Jakarta: Cetakan V. Sel. Penebar Swadaya.

Hussain, M. A., Al Mamun, A., Peters, S. A., Woodward, M., \& Huxley, R. R. (2016). The Burden of Cardiovascular Disease Attributable to Major Modifiable Risk Factors in Indonesia. Journal of epidemiology, 26(10), 515-521. doi: https://doi.org/10.2188/jea.JE20150178

Japardi, I. (2002). Patomekanisme Stroke InfarkAterotrombotik. Medan: Fakultas Kedokteran, Universitas Sumatera Utara.

Jia, Y.-J., Liu, J., Guo, Y.-L., Xu, R.-X., Sun, J., \& Li, J.-J. (2013). Dyslipidemia in rat fed with high-fat diet is not associated with PCSK9-LDL-receptor pathway but ageing. Journal of geriatric cardiology : JGC, 10(4), 361-368. doi:https://doi.org/10.3969/j.issn.1671-5411.2013.04.007

Lamanema, M. E. L. (2005). Perbandingan Profil Lipid Dan Perkembangan Lesi Aterosklerosis Pada Tikus Wistar Yang Diberi Diet Perasan Pare Dengan Diet Perasan Pare dan Statin (The Comparison of Lipid Profile and The Progression of Atherosclerotic Lesion between Momordica Charantia Juice Dietary with and without Statin on Wistar Rats). Tesis. Program Pasca Sarjana, Universitas Diponegoro Semarang.

Lenny, S. (2006). Senyawa Flavonoida, Fenilpropanoida dan Alkaloida. Skripsi. Medan: Fakultas Matematika dan Ilmu Pengetahuan Alam, Universitas Sumatera Utara.

Mills, S., \& Bone, K. (2000). Principles and practice of phytotherapy. Modern Herbal Medicine. UK: Churchill Livingstone.

Murray, RK., D.K Granner, P.A. Mayes, dan V.W. Rodwell. (2008). Biokimia Harper. Edisi 25. Jakarta: Penerbit Buku Kedokteran EGC. 
Ruel, G., Pomerleau, S., Couture, P., Lemieux, S., Lamarche, B., \& Couillard, C. (2006). Favourable impact of low-calorie cranberry juice consumption on plasma HDL-cholesterol concentrations in men. British Journal of Nutrition, 96(2), 357364. doi:https://doi.org/10.1079/BJN20061814

Sawangjaroen, N., Sawangjaroen, K., \& Poonpanang, P. (2004). Effects of Piper longum fruit, Piper sarmentosum root and Quercus infectoria nut gall on caecal amoebiasis in mice. Journal of Ethnopharmacology,91(2-3), 357-360. doi:https://doi.org/10.1016/j.jep.2004.01.014

Smeriglio, A., Barreca, D., Bellocco, E., \& Trombetta, D. (2017). Proanthocyanidins and hydrolysable tannins: occurrence, dietary intake and pharmacological effects. British journal of pharmacology,174(11), 1244-1262. doi: https://doi.org/10.1111/bph.13630

Sutedjo, A. Y. (2006). Mengenal penyakit melalui hasil pemeriksaan laboratorium. Yogyakarta: Amara Books.

Syamsuhidayat, S. S., \& Hutapea, J. R. (1991). Inventaris tanaman obat Indonesia. Jakarta: Departemen Kesehatan Republik Indonesia.

Uli, R. E., Satyana, R. P., Zomer, E., Magliano, D., Liew, D., \& Ademi, Z. (2020). Health and productivity burden of coronary heart disease in the working Indonesian population using life-table modelling. BMJ open, 10(9), e039221. doi:http://dx.doi.org/10.1136/bmjopen-2020-039221

Valacchi, G., Belmonte, G., Miracco, C., Eo, H., \& Lim, Y. (2014). Effect of combined mulberry leaf and fruit extract on liver and skin cholesterol transporters in high fat diet-induced obese mice. Nutrition research and practice, 8(1), 20-26. doi:https://doi.org/10.4162/nrp.2014.8.1.20

Wierda, R. J., Geutskens, S. B., Jukema, J. W., Quax, P. H., \& van den Elsen, P. J. (2010). Epigenetics in atherosclerosis and inflammation. Journal of cellular and molecular medicine, 14(6a), 1225-1240. doi: https://doi.org/10.1111/j.15824934.2010.01022.x

Xu, S., Pelisek, J., \& Jin, Z. G. (2018). Atherosclerosis is an epigenetic disease. Trends in Endocrinology \& Metabolism, 29(11), 739-742. doi: https://doi.org/10.1016/j.tem.2018.04.007

Zeka, K., Ruparelia, K., Arroo, R. R., Budriesi, R., \& Micucci, M. (2017). Flavonoids and their metabolites: prevention in cardiovascular diseases and diabetes. Diseases, 5(3), 19. doi:https://doi.org/10.3390/diseases5030019

Zhang, X., Jin, Y., Wu, Y., Zhang, C., Jin, D., Zheng, Q., \& Li, Y. (2018). Antihyperglycemic and anti-hyperlipidemia effects of the alkaloid-rich extract from barks of Litsea glutinosa in ob/ob mice. Scientific reports, 8(12646), 1-10. doi:https://doi.org/10.1038/s41598-018-30823-w 